\title{
Development and In Situ Characterization of New Electrolyte and Electrode materials for Rechargeable Lithium Batteries
}

\author{
FINAL ABSTRACT \\ ON CRADA WITH GOULD, INC. \\ CRADA No. BNL C-97-08 \\ (July 1997-----July 1998) \\ RECEIVED \\ JAM $O 32000$ \\ OSTI
}

\author{
Xiao-Qing Yang \\ Department of Applied Science \\ Brookhaven National Laboratory * \\ X. K. Xing and M. Daroux \\ Gould Electronics Inc., Powerdex Division
}

* Under contract No. DE-AC02-98CH10886 with the

U.S. Department of Energy 


\section{DISCLAIMER}

This report was prepared as an account of work sponsored by an agency of the United States Government. Neither the United States Government nor any agency thereof, nor any of their employees, make any warranty, express or implied, or assumes any legal liability or responsibility for the accuracy, completeness, or usefulness of any information, apparatus, product, or process disclosed, or represents that its use would not infringe privately owned rights. Reference herein to any specific commercial product, process, or service by trade name, trademark, manufacturer, or otherwise does not necessarily constitute or imply its endorsement, recommendation, or favoring by the United States Government or any agency thereof. The views and opinions of authors expressed herein do not necessarily state or reflect those of the United States Government or any agency thereof. 


\section{DISCLAIMER}

Portions of this document may be illegible in electronic image products. Images are produced from the best available original document. 
Project \#: $\quad$ BNL C-97-08

Project Status: Completed

\title{
Title: Development and In Situ Characterization of New Electrolyte and Electrode materials for Rechargeable Lithium Batteries
}

\begin{abstract}
Proposal:
The object of this project is to develop new electrolyte and cathode materials for rechargeable lithium batteries, especially for lithium ion and lithium polymer batteries. Enhancing performance, reducing cost, and replacing toxic materials by environmentally benign materials, are strategic goals of DOE in lithium battery research. This proposed project will address these goals on two important material studies, namely the new electrolytes and new cathode materials. For the new electrolyte materials, aza based anion receptors as additives, organic lithium salts and plasticizers which have been developed by BNL team under Energy Research programs of DOE, will be evaluated by Gould for potential use in commercial battery cells. All of these three types of compounds are aimed to enhance the conductivity and lithium transference number of lithium battery electrolytes and reduce the use of toxic salts in these electrolytes. BNL group will be working closely with Gould to further develop these compounds for commercialization. For the cathode material studies, BNL efforts will be focused on developing new superior characterization methods, especially in situ techniques utilize the unique user facility of DOE at BNL, namely the National Synchrotron Light Source (NSLS). In situ x-ray absorption and x-ray diffraction spectroscopy will be used to study the relationship between performance and the electronic and structural characteristics of intercalation compounds such as $\mathrm{LiNiO}_{2}, \mathrm{LiCoO}_{2}$, and $\mathrm{LiMn}_{2} \mathrm{O}_{4}$ spinel. The study will be focused on $\mathrm{LiMn}_{2} \mathrm{O}_{4}$ spinel materials. Gould team will contribute their expertise in choosing the most promising compounds, providing overall performance requirements, and will use the results of this study to guide their procedure for quality control. The knowledge gained through this project will not only benefit Gould and $\mathrm{BNL}$, but will be very valuable to the scientific community in battery research.
\end{abstract}




\section{Significant accomplishments:}

The tasks defined in our proposal were successfully completed by both BNL and Gould. BNL teams.

1. A new family of boron based electrolyte system has been developed at BNL. This system is a much better system than the aza based anion receptors. The solubility of the boron based compounds is much higher than the aza based compounds. Using these boron based compounds as additives, $\mathrm{LiF}$ and other salts, which are not soluble in organic solvents, were dissolved in non-aqueous solutions. These electrolytes were tested in liquid lithium battery cells at BNL. For the first time, lithium fluoride has been successfully used as conducting salt in a novel non-aqueous electrolyte. This was accomplished by using $\mathrm{LiF}$ together with one of the newly synthesized boron based anion receptor as additive in 1,2-dimethoxyethane (DME). With the strong anion complexation effect of the additive, the solubility of LiF in DME was increased to as high as $1 \mathrm{M}$ and the conductivity of the solution was $6.8 \times 10^{-3} \mathrm{~S} / \mathrm{cm}$. This new electrolyte was electrochemically stabile up to $4.46 \mathrm{~V}$ on glassy carbon working electrode. The feasibility of this new electrolyte in rechargeable lithium battery was studied. A testing cell with $\mathrm{LiMn}_{2} \mathrm{O}_{4}$ cathode and new electrolyte was cycled between $3.5 \mathrm{~V}$ and $4.3 \mathrm{~V}$ for 51 times. The initial capacity is very closed to the cell with commercial electrolyte (LiPF 6 in PC-EC-DMC $(1: 1: 3)$ (propylene carbonate-ethylene carbonate-dimethyl carbonate). Obvious Capacity fading was observed during cycling. The charge-discharge characteristic and cyclic voltammgram showed the capacity fading may be due to the partial electrochemical decomposition of the electrolyte.

2. The most significant accomplishments were made in the field of cathode materials studies. $\mathrm{LiMn}_{2} \mathrm{O}_{4}$ materials from three different commercial sources were provided by Gould to BNL team. In situ XRD studies were carried out by BNL team. Some of the results have been published, others are being analyzed or evaluated. $\mathrm{LiNi}_{0.8} \mathrm{Co}_{0.2} \mathrm{O}_{2}$ and other new cathode materials have been provided to BNL by Gould, the results of in situ studies of these materials will be published soon.

In Situ x-ray diffraction studies on $\mathrm{Li}_{x} \mathrm{Mn}_{2} \mathrm{O}_{4}$ spinel cathode materials during chargedischarge cycles were carried out using a Synchrotron as the $\mathrm{x}$-ray source. Lithium rich $(x=1.03-1.06)$ spinel materials, obtained from two different sources, were studied. For the first time, three cubic phases, rather than only two as reported in the literature, were observed during charge-discharge cycles in all the samples when a sufficiently low chargedischarge rate $(\leq \mathrm{C} / 10)$ was used. There are two regions of two-phase coexistence, indicating that both phase transitions are first order. The separation of the Bragg peaks representing these three phases varies from sample to sample and also depends on the charge-discharge rate. These results show that the de-intercalation of lithium in lithium-rich 
spinel cathode materials proceed through a series of phase transitions from a lithium-rich phase to a lithium-poor phase and finally to a $\lambda-\mathrm{MnO}_{2}$-like cubic phase, rather than through a continuous lattice constant contraction in a single phase.

3. Two types of battery cells for in situ study have been developed by BNL and Gould. The cell developed by Gould is a polymer gel lithium ion cell, and the one developed by BNL is a cell using liquid electrolytes. No beryllium windows were used in these cells. It enabled us to do the in situ studies at high voltages which is very important to the lithium battery research, and very little work has been published in the literature so far.

In order to develop safer, cheaper, and better performance cathode materials, the in-depth understanding of the relationships between the thermal stability and structure, performance and structure are very important. X-ray diffraction (XRD) is one of the most powerful tools to study these relationships. However, all the in situ and ex situ XRD studies on the cathode materials published so far have been using conventional $x$-ray sources probe the cell in reflection geometry. Therefore, the observed structural changes are predominantly from the top few microns of the electrode coating, which might not be representative for the whole coating during charge-discharge especially when the rate is high. Two types of new in situ XRD lithium battery cells were designed for using the strong $x$-ray source from synchrotron light source. The beryllium windows were replaced by Mylar windows or plastic bags. The electrodes were incorporated into the cells with a $\mathrm{Li}$ foil negative electrode, a Celgard separator, and $1 \mathrm{M} \mathrm{LiPF}_{6}$ electrolyte in 1:1 EC:DMC solvent. Taking the advantage of the strong beam, the experiments were carried out in the transmission mode and the cell configuration is similar to the real battery cells. Two cathode material systems, the $\mathrm{LiMn}_{2} \mathrm{O}_{4}$ and a family of $\mathrm{LiCo}_{x} \mathrm{Ni}_{1-\mathrm{x}} \mathrm{O}_{2}(\mathrm{x}=0.0,0.1$ and 0.2$)$ were studied using this synchrotron based in situ XRD. The in situ XRD measurements were made at Beam Line X18A at National Synchrotron Light Source (NSLS) at Brookhaven National Laboratory. The beam line was operated at an energy of 10.375 $\mathrm{keV}(\lambda=1.195 \AA)$ which also offered the advantage of increased penetration depth over the conventional $\mathrm{Cu} \mathrm{k} \alpha$ x-ray source. In the studies of the $\mathrm{LiCo}_{x} \mathrm{Ni}_{1-\mathrm{x}} \mathrm{O}_{2}$ system, the relationship between the structural changes during charge-discharge and the thermal stability was investigated. Since the thermal stability problem mainly occurred at fully charged or over-charged state for cathodes, the structural changes in the voltage range from 4.1V to $5.1 \mathrm{~V}$ is very important. By eliminating the beryllium windows, we are able to do the in situ XRD studies in this high voltage range. As far as we know, only one other research group (Dr. Amatucci's group at BellCore.) has done some similar experiments so far. Systematic studies of the correlation between the thermal stability and the characteristic structural change behavior of these cathode materials during overcharge have been carried out for the first time by BNL-Gould team. These results will be published soon. 


\section{Significant problems:}

No significant problems were encountered for this project.

\section{Industry benefits realized:}

For the Gould team, by collaborating with BNL team, the unique facility such as National Synchrotron Light Source at BNL was utilized for important battery material studies. Very useful information about the relationship between performance and structural changes of the $\mathrm{LiMn}_{2} \mathrm{O}_{4}$, $\mathrm{LiCoO}$, and $\mathrm{LiCo}_{x} \mathrm{Ni}_{1-x} \mathrm{O}_{2}$ cathode materials was obtained through the in situ X-ray absorption and diffraction studies. These results were used for their development efforts on new thin film lithium ion batteries.

\section{BNL benefits realized:}

For the BNL team, the thin film rechargeable lithium battery cells designed and constructed by Gould team is one of the most important factors for their success of in situ X-ray absorption and diffraction studies. Based on the experience gained from these cells, BNL team designed and constructed a series of new in situ cells for X-ray diffraction and X-ray absorption studies. The knowledge gained through working together with Gould is not only valuable to Gould for developing their commercial lithium batteries, but also very important to BNL for the fundamental understanding of $\mathrm{Li}$ intercalation process in cathode materials and the effects of the anion receptors in the new generation of electrolytes.

\section{Future works:}

More in situ x-ray absorption and diffraction studies have been planned by both BNL and Gould teams. The relation between the synthesis conditions and structural changes of $\mathrm{LiMn}_{2} \mathrm{O}_{4}$ cathode materials during charge-discharge cycles, the effects of overcharge and over discharge, the structural changes related to cycle life, the structural changes during charge-discharge at high and low temperatures will be studied. These studies is under way through a new multi-year CRADA (BNL-98-04). 


\section{Publications and Presentations}

X. Q. Yang, H. S. Lee, C. Xiang, J. McBreen, L. S. Choi, Synthesis of Anion Receptor Grafted Siloxane Polymers and the Ionic Conductivity Studies of Polymer-Salt Complexes, presented at the 1997 Joint International Meeting of the Electrochemical Society and the International Society of Electrochemistry (August 31 to September 5, 1997, Paris, France).

R. Thurston, X. Q. Yang, S. Mukerjee, N. M. Jisrawi, J. McBreen, M. L. Daroux, and X. K. Xing, Structural Evolution of $\mathrm{Li}_{X} \mathrm{Mn}_{2} \mathrm{O}_{4}$ measured In Situ Using Synchrotron X-ray Diffraction, presented at the 1997 Joint International Meeting of the Electrochemical Society and the International Society of Electrochemistry (August 31 to September 5, 1997, Paris, France).

S. Mukerjee, T. R. Thurston, M. Jisrawi, X. Q. Yang, J. McBreen, M. L. Daroux, and X. K. Xing, Structural Evolution of $\mathrm{Li}_{x} \mathrm{Mn}_{2} \mathrm{O}_{4}$ in Lithium-Ion Battery Cells Measured In Situ Using Synchrotron X-ray Diffraction Techniques, Journal of the Electrochemical Society, 145, 4.66. (1998)

X. Sun, H. S. Lee, S. Lee, X. Q. Yang,, and J. McBreen, A Novel Lithium Battery Electrolyte Based on Lithium Fluoride and a Tris(pentafluorophenyl) Borane Anion Receptor in DME, Electrochemical and Solid State Letters, 1, 239(1998)

X. Q. Yang, X. Sun, S. J. Lee, S. Mukerjee, J. McBreen, M. L. Daroux , and X. K. Xing, In Situ Xray Diffraction Studies of $\mathrm{Li}_{x} \mathrm{Mn}_{2} \mathrm{O}_{4}$ Cathode Materials by Synchrotron X-ray Radiation, the Lithium Proceeding Volumes of the $194^{\text {th }}$ Meeting of Electrochemical Society, Boston, Massachusetts, Nov. 1-6 1998. (submitted)

H. S. Lee, X. Q. Yang, C. Xiang, J. McBreen, L. S. Choi, Synthesis of A New Family of Boron Based Anion Receptors and the Studies of Their Effect on Ion Pair Dissociation and Conductivity of Lithium Salts in Non-Aqueous Solutions, Journal of the Electrochemical Society, 145, 2813(1998)

X. Sun, H. S. Lee, S. Lee, X. Q. Yang,, J. McBreen, and L. S. Choi, Synthesis and Studies of Boron Based Anion Receptors and Their Use as Non-Aqueous Electrolytes for Lithium Batteries, Abstract submitted to the $194^{\text {th }}$ Meeting of Electrochemical Society, Boston, Massachusetts, Nov. 1-6 1998.

J. McBreen, S. Mukerjee and X. Q. Yang, In situ Synchrotron X-ray Studies of Battery and Fuel Cell Materials, Synchrotron Radiation News, 11, 18 (1998)

Y. Ein-Eli, S. H. Lu, M. A. Rzeznik, S. Mukerjee, X. Q. Yang, and J. McBreen, $\mathrm{LiCu}_{\mathrm{x}} \mathrm{Mn}_{2-\mathrm{x}} \mathrm{O}_{4}$ Spinels $(0.1<\mathrm{x}<0.5)$ : A New Class of Cathode Materials for Li Batteries, Journal of the Electrochemical Society, 145, 3383(1998) 
Y. Ein-Eli, J. T. Vaughey, M. M. Thackeray, S. Mukerjee, X. Q. Yang, and J. McBreen, $\mathrm{LiCu}_{0.5}$ ${ }_{x} \mathrm{Mn}_{1.5} \mathrm{O}_{4}$ Spinel electrodes, Superior High-potential Cathode Materials for Li Batteries. I. Electrochemical and Structural Studies. Journal of the Electrochemical Society, 146, 908 (1998) 